\title{
Exame andrológico em garanhões
}

Gustavo Henrique Zimmermann Winter, MV, MSc, PhD.

Porto Alegre, RS.

ISSUE DOI: $10.3738 / 1982.2278 .1131$

Os critérios de seleção e uso de um garanhão envolvem sua performance, conformação e pedigree sem considerar, muitas vezes, sua eficiência reprodutiva. Muitos fatores influenciam a libido, a habilidade de monta e até mesmo a coleta de sêmen. Estes fatores podem ser hereditários, relacionados ao meio ambiente ou adquiridos; e são altamente influenciados pelo manejo do garanhão. O objetivo do exame andrológico é avaliar a capacidade reprodutiva do garanhão: conhecer a qualidade dos espermatozoides em conjunto com os diversos fatores que compõem a saúde reprodutiva. $\mathrm{O}$ exame andrológico deve ser realizado em todos os garanhões, inclusive nos garanhões jovens em início de trabalho. A maioria dos exames realizados tem caráter curativo, e só são requisitados quando se percebe um problema na eficiência reprodutiva do garanhão ou problema específico na genitália externa. No entanto, deveriam ter caráter preventivo e serem realizados antes de cada temporada de monta ou logo no seu início. Com o laudo em mãos é possível adotar as melhores condutas para o manejo reprodutivo. Outro momento importante para realizar o exame andrológico é na compra e venda de garanhões. $\mathrm{O}$ fato de um garanhão ter filhos não garante a sua fertilidade para temporadas futuras. Nestas transações o laudo andrológico auxilia na tomada de decisões do comprador ao mesmo tempo em que serve de garantia ao vendedor. Importante salientar que um exame andrológico não é apenas um laudo da motilidade espermática ou o resultado do chamado "espermograma”. A avaliação das potências Generandi (espermatogênese) e Coeundi (libido) deve ser realizada em todos os exames andrológicos, sendo essencial o profundo conhecimento da fisiologia reprodutiva do garanhão. Destacam-se a regulação hormonal, a própria espermatogênese e a etologia da cópula. $\mathrm{O}$ exame andrológico inicia com a resenha e anamnese. Avalia-se então a saúde geral do garanhão: estado nutricional, sistema circulatório, locomotor, dentição, laringe e olhos. A genitália externa deve ter desenvolvimento compatível com a idade e raça. Pela palpação se avalia a posição, simetria e consistência dos testículos, que devem estar livres, móveis e indolores na bolsa escrotal. Igualmente avaliam-se os epidídimos e cordões espermáticos. A ultrassonografia é empregada em todos os exames andrológicos para avaliação morfológica dos testículos, epidídimos e cordões espermáticos. Eventualmente pode ser realizado o exame por palpação e ultrassonografia das glândulas acessórias do trato reprodutivo. A bacteriologia e endoscopia podem ser realizadas 
como exames complementares. $\mathrm{O}$ exame do sêmen, coletado por vagina artificial, deve ser analisado fresco e diluído. Avalia-se o volume sem gel do ejaculado, cor, odor, $\mathrm{pH}$, motilidade e vigor espermático, além da concentração e número total de espermatozoides do ejaculado. A morfologia é avaliada em 200 células espermáticas. Garanhões em repouso sexual requerem duas coletas com $1 \mathrm{~h}$ de intervalo para melhor estimar a reserva extra-gonadal. Diferentes diluentes de sêmen e estocagem a $5^{0} \mathrm{C}$ são testados. Exames adicionais de integridade e funcionalidade de membrana são realizados em centros de referência, bem como análise computadorizada de motilidade (CASA). Um laudo de avaliação andrológica deve ser confeccionado com o máximo de informações possíveis, diagnóstico, prognóstico e comentários relevantes.

Palavras-chave: Equinos, reprodução, machos. 